Repercussions of Coronavirus pandemic and its impact on the Aesthetic Variables of Contemporary Visual Art and Artists

\title{
Repercussions of Coronavirus pandemic and its impact on the Aesthetic Variables of Contemporary Visual Art and Artists
}

\author{
Abeer Nasser Al Ghanim
}

\begin{abstract}
The COVID-19 pandemic had a sudden and substantial impact on visual arts, culture, and the creative economy. This study elaborates on the effects of the Coronavirus (COVID-19) crisis on the creative economy, which is comprised of film, advertising, and fashion as well as creative occupations such as musicians, artists, performers, and designers. The global health crisis and the uncertainly resulting from it profoundly affected organizations' operations as well as individuals - both employed and independentespecially across the sector of visual arts.

To understand how Art careers are changing due to the Coronavirus, this paper aims to investigate the effect of the Coronavirus outbreak on the artists' careers and their response to propose a new creative aesthetic approach to the Art industry all over the world through description and analysis of some Art applications both technically and functionally in contemporary spaces of visual arts.

In the end, the researcher concluded that there were many commonalities in how artists were responding to the shifting professional landscape around them. While most of the artists experienced a level of loss from sales, delayed workshops, and cancelled openings, they were already planning ways to innovate and move their careers to online websites
\end{abstract}

Keywords: Coronavirus, Covid-19, Contemporary art, Aesthetic, Variables

\section{Introduction}

As the Coronavirus pandemic unfolds across the globe, threatening lives and upending the world economy while governments struggle with new lockdown measures to tackle the spread of the unpredicted virus the economies and businesses are counting the costs. Despite the development of new vaccines, many are still wondering when the world will really recover and 
go back to the way it was before the chaos struck. The validity of the most predictive path relies on numerous elements, involving biological, cultural, and social characteristics which are often unknown or highly uncertain on the other hand, the immediate impacts of the COVID-19 pandemic were predictable and severe. Lockdowns and restrictions on people congregating and moving to threaten an already fragile sector across the globe. Revenue was lost, employment was falling, supply chains are disrupted, meanwhile, the economic downturn and restricted movement also affect the wider population where existing inequities are amplified whether it was racial, socioeconomic, generational, or spatial.

The pandemic also reveals where culture is most resilient. If cities act decisively for recovery and reinvention, the cultural ecosystem can reconfigure. New organizations and cultural forms can emerge. Cities can support longer-term sustainability through new models of partnership and funding. And build cultural equity into the heart of their response.

Undoubtedly COVID-19 is changing our society and challenging long-held traditions and habits. It will impact us for years beyond the immediate crisis in every aspect of our lives, like many other societies and businesses, the Art community has been heavily disrupted by the worldwide impact of the Covid-19 virus, and artists can expect more shifts to persist for some time. Due to these turbulent times, many spring auction sales have been postponed, Art fairs have been either postponed or cancelled and galleries and auction houses have had to close their doors to the public under government mandates. This physical distancing has resulted in challenges to the artists' ability to physically inspect the instant emotional reactions of his Art audience and present the artwork to the public, all of these repercussions contributed one way or another to exert influence on the aesthetic variables of the artist expressive vision and approach methods to obtain his Artwork. 
Repercussions of Coronavirus pandemic and its impact on the Aesthetic Variables of Contemporary Visual Art and Artists

This study considered a part of the scientific attempts to identify and comprehend the impact of the Coronavirus pandemic with all its repercussions of the aesthetic variables of contemporary Art methods and artists overall. This impact challenged the artists' abilities to come up with a new visionary expression, and aesthetics, influences, attitudes and approaches to get out of this crisis with works of Art that mimic reality and defines the concept of artistic knowledge and contributes towards community recovery and development.

This study comprises four axes; the first includes the problem of research and need, the second is the theoretical framework, which is divided onto three main sections, the first summarizes the impact of the Coronavirus pandemic on society and Art community and industry in specific, as the second explores Art organizations and their response to the shifting professional landscape around them some of the solutions that they came up with to overcome the obstacles imposed by the epidemic. While the third section deals with the impact of the crises on the artists' visual aspects of his methods and aesthetic approach.

The third axes include the applied practical framework, which consisted of critique and analysis of some of the relevant works of Art in which the researcher resorted to finding the realistic application of the theoretical framework. Finally, the fourth axes summarize the conclusions and recommendations of the researcher and the conclusions that achieve the desired objectives.

\section{The Research problem and the need for it}

\subsection{Research Question:}

The research problem was as follows: What is the impact of repercussions of Coronavirus pandemic on the esthetic variables of contemporary Art and artist? What are the new methods and approaches brought by the artist to overcome the difficulties and consequences that were imposed by the pandemic? 


\subsection{Significance of this study:}

The importance of the study lies in illuminating the conceptual visionary and aesthetic aspects that were brought by artists around the globe during the Coronavirus pandemic and helped them overcome the obstacles imposed by it and come up with new methods and approaches that enrich the cognitive and esthetic aspect by presenting a modern study that draws the dimensions of contemporary in the Fine Art scene, which highlights the formal and stylistic variables in modern Art and standing on the main fixed features that leverage contribution to the community after crises recovery. The research also supports the positive side of the behavior of individuals through the creative interaction between the environment and the issues of interest.

\subsection{Purpose of Study:}

The research aims to reveal the impact Coronavirus pandemic on the esthetic variables across the spectrum of artistic and creative endeavors, on the other hand, it focuses on the important role of the artist and his creative skills and approach methods that contribute to presenting a new vision for artistic expression under unprecedented times.

\subsection{Methodology:}

A descriptive-analytical methodology is used in this study for being the appropriate method to use for studying a phenomenon as in this research which expresses the applied framework well as its features to reach the goal objectives. through criticism and analysis of some artwork related to the subject of research, including highlighting the pioneering role of Art in changing concepts and developing awareness of society through the most important artists 
Repercussions of Coronavirus pandemic and its impact on the Aesthetic Variables of Contemporary Visual Art and Artists

\subsection{Study Limits:}

- Objective limits: This research is determined by repercussions of the Coronavirus pandemic and its impact on the aesthetics variables of contemporary Art and artists.

- Time limits: The first period of the twenty-first century and the beginning of the coronavirus pandemic. - Spatial limits: all around the world.

\subsection{Terminology of the Study:}

- Coronavirus disease 2019 (COVID-19) is a contagious disease caused by severe acute respiratory syndrome coronavirus 2 (SARS-CoV-2). The first case was identified in Wuhan, China, in December 2019. The disease has since spread worldwide, leading to an ongoing pandemic (Page et al., 2021).

- Aesthetics may be defined narrowly as the theory of beauty, or more broadly as that together with the philosophy of art. The traditional interest in beauty itself broadened, in the eighteenth century, to include the sublime, and since 1950 or so the number of pure aesthetic concepts discussed in the literature has expanded even more. Traditionally, the philosophy of Art concentrated on its definition, but recently this has not been the focus, with careful analyses of aspects of Art largely replacing it. Philosophical aesthetics is here considered to center on these latter-day developments.

Thus, after a survey of ideas about beauty and related concepts, questions about the value of aesthetic experience and the variety of aesthetic attitudes will be addressed, before turning to matters which separate Art from pure aesthetics, notably the presence of intention. That will lead to a survey of some of the main definitions of Art which have been proposed, together with an account of the recent "de-definition" period. The concepts of expression, representation and the nature of Art objects will then be covered. (Slater, 2003). 
- Variable: Indicates a specific attribute that addresses several states, values, or properties that somehow affect something else, it also can refer to the "transformations that occur in society in a certain period and can generally benefit the sudden and definitive mutation of anything, and its consequences on the extent of the circumstances surrounding it." (Laland,2001,p.148).

-Contemporary Art is the Art of today, produced in the second half of the 20th century or the 21st century. Therefore Contemporary is the historical period that is immediately relevant to the present and is a certain perspective of modern history. And the contemporary artists do work in a globally influenced, culturally diverse, and technologically advancing world. (Essak,2002)

Their Art is a dynamic combination of materials, methods, concepts, and subjects that continue the challenging of boundaries that was already well underway in the 20th century. Diverse and eclectic, contemporary Art as a whole is distinguished by the very lack of a uniform, organizing principle, ideology, or "-ism". Contemporary Art is part of a cultural dialogue that concerns larger contextual frameworks such as personal and cultural identity, family, community, and nationality. In vernacular English, modern and contemporary are synonyms, resulting in some conflation of the terms modern Art and contemporary Art by non-specialists (NYU Steinhardt,2019)

Some define "contemporary Art as Art produced within "our lifetime," recognizing that lifetimes and life spans vary. However, there is a recognition that this generic definition is subject to specialized limitations "(Essak,2013) "Strictly speaking, the term "contemporary art" refers to Art made and produced by artists living today"(Getty,2019) 
Repercussions of Coronavirus pandemic and its impact on the Aesthetic Variables of Contemporary Visual Art and Artists

\section{Theoretical framework}

\section{1 -The beginning of the chaos}

COVID-19 has had undeniable and horrific consequences on people's lives and the economy. With sickness, death and unemployment rates soaring almost everywhere on our planet, it is easy to despair.

The novel coronavirus outbreak, "which began in Wuhan, China, in December 2019, a year later it has expanded to touch every corner of the globe. Millions of people around the world have been sickened and hundreds of thousands of others have died" ( Schumaker,2020)

According to official reports, As many as 213 countries and territories have registered COVID-19 cases, and the entire world is buzzing with uncertainty and questions about it.

At the moment, many countries have taken measures, some of them stringent to slow down the spread of the virus. While some of these countries are now considering whether to ease the measures, others have already decided to keep them in place over the following weeks.

Many countries have declared restrictive measures, such as lockdown, shelter in place, or stay at home orders, to contain the pandemic at a local level. However, the wildly differing responses and response timelines have left people wondering if authorities failed to take the situation seriously early on when they could have done more to slow down the spread of the coronavirus.

"China appeared to manage the coronavirus outbreak effectively, putting in place early travel bans within the country itself. As early as January 23, Chinese authorities declared a nationwide travel ban, which, some experts suggest, may have averted over 700,000 COVID-19 cases within the country"(Cohut.2020).

Earlier in April 2020, China eased the lockdown measures in Wuhan, the original epicenter of the new coronavirus 
outbreak, amid celebrations that the nation had beaten the virus. Nevertheless, a recent study assessing the likely number of COVID-19 deaths in the country suggests that the virus may have hit even harder than the authorities initially thought. Given the development of the situation in China, many people have been questioning the appropriateness of measures that other countries around the world have taken Some European countries have reacted sooner to the steep rise in COVID-19 cases than others. On March 10, Italy ordered a strict nationwide lockdown, becoming the first country in Europe to do so. the government banned all travel in the country, and people could only leave their homes for essential reasons - such as to buy food. When going out, people had to carry declaration forms and wear face masks and disposable gloves." (Cohut,2020)

\subsection{The impact on people lives}

Despite a slowdown in the growth of new COVID-19 cases, governments have recently extended lockdown measures fearing the epidemic wave. And this scene was repeated in almost every country around the world, Strict laws were put in place to contain the spread of the epidemic, curfews, maintaining safe distances, preventing gatherings and social activities, closing businesses, forcing people to work from home or being homeschooled, struggling financially to support themself or their families, unable to travel even down the street to visit friends, suffering the loss of beloved ones, till the point that experts were worry that people all over the world may be experiencing an increasing number of mental health issues.

This certainly came across loud and clear from the many responses that were received from people across the globe. Some people have also spoken about how the specific measures in their country have affected their physical health as well."Some people complain about how physical distances has affected them, families are dealing with an increased amount of stress and physical discomfort due to lack of exercise and socializing. some experience anxiety attacks emotional fluctuations such as the 
Repercussions of Coronavirus pandemic and its impact on the Aesthetic Variables of Contemporary Visual Art and Artists

feeling of loneliness, fear, anger, depression, sadness, loss of interest, physical health was also in jeopardy citizens were complaining from backaches, headaches, sight problems, eating disorders, Indigestion and nerve problems and a lot more" (Cohut,2020).

On the other hand, the pandemic has forced many people to work - or being schooled from home may seem like the dream set-up for some, as it offers the possibility to tap into that latent creativity from the comfort of a cozy, familiar environment, However, it can also bring a unique set of challenges especially as an enforced measure, "While being able to work from home can empower and up-level our working life is taken to the extreme. In many cases, the boundaries between home life and work-life can become blurred, and these boundaries are what enable us to stay healthy and well" (Cohut,2020).

In an enforced work from home situation, people may end up continuously sharing a space with other family members, and they may start to feel as though they have to attend to both domestic tasks and work assignments at the same time. This blending of home and work life may also lead to working longer hours than usual.

For that boundaries have to be set so a person does not become overwhelmed with competing tasks is to create a physical space that is for work only, where the person will not face nonwork-related disruptions and interruptions.

Looking at the bright side many benefits came out through time, spending more time with the children and the joy of extra family time and getting to know neighbors are one of those benefits, the pandemic has provided a unique opportunity to reconnect, create memories and evaluate priorities" (Gummer, 2021).", the rhythm of the busy life before did not give enough time to relax and do nothing because that constant pressure on people, to feel, to do things, to achieve, to compete, to turn up to 
everything, to have a full diary has been removed due to lockdown and forcing people to stay in (Hodgkinson,2020)

The environmental benefits were promising, due to planes being grounded, cars parked, and factories shut down is unquestionable. Across the world, carbon emissions have fallen, and air quality has risen. The response to the pandemic has given us a glimpse that another safer healthier world is possible. (Bartle,2020)

As the coronavirus drastically alters our day-to-day life, at least for the time being, many have observed that life on earth will never be the same. The impact of the virus and social distancing measures is apparent worldwide.

\subsection{The effect on the Art industry}

The COVID-19 pandemic has had a humbling impact on many industries including the luxury sectors and the $\$ 64$ billion Art market. With the coronavirus spreading across the world, many Art museums, fairs, and biennials have begun to take precautions. Some have been forced to close for extended periods, and others have postponed major events. To take stock of the coronavirus's impact on the Art world.

Through the first quarter of 2020, arts and culture sector organizations around the world progressively restricted their public activities and then closed completely due to the pandemic. Starting with China, East Asia, and then worldwide, by late March most cultural heritage organizations had closed, and Art events were postponed or cancelled, either voluntarily or by government mandate. This included galleries, libraries, archives, and museums, as well as film and television productions, theatre and orchestra performances, concert tours, zoos, and music and arts festivals. Following the rapidly evolving news of closures and cancellations across the world throughout February and March, as of April 2020 dates for reopening and expectations for when the cultural organization can fully "return to normal" remained undetermined for most of the 
Repercussions of Coronavirus pandemic and its impact on the Aesthetic Variables of Contemporary Visual Art and Artists

world. Equally, the long-term financial impacts upon them will vary greatly, with existing disparities especially for institutions without an endowment fund being exacerbated. (Wikipedia, 2020)

As key gatekeepers in the Art world, gallerists promote artists to both cultural institutions and collectors (Becker, 1982, p 23) and due to the pandemic Art galleries sales fell by an average of $36 \%$ in the first half of this year, finds the first comprehensive analysis of the impact of Covid-19 on this sector, nearly all the galleries $(93 \%)$ had to shut their doors for an average of 10 weeks during the first half of this year. While most have since reopened, the report notes that their situation could yet worsen as deadlines loom for emergency relief such as furlough schemes and rent reductions, To make up for some lost sales, galleries have made decent strides online, which has proved a "lifeline" Adjustment to a more digital world is still shaky in this industry, but most galleries expect their online business to keep growing and be a sustainable income stream into 2021. (Melanie Gerlis,2020)

With COVID quarantine, virtual tours have perhaps become the greatest form of escapism, enabling millions to leave their home and visit major museums and other Art venues. Museums around the world are competing to provide the most comprehensive or intriguing tours.

Many museums have turned to their existing social media presence to engage their audience online. Interestingly, China was the first country to enforce quarantine but also the first to provide digital services, primarily for a domestic audience. Others also have been successful with social media content strategies such as the Getty Museum for incorporating its works into the popular video game Animal Crossing. Likewise, the Shedd Aquarium in Chicago has had the brilliant idea of filming their penguins visiting other animals: the Shedd Aquarium in Chicago for filming their penguins visiting other animals, Meanwhile, over in Europe, the Royal Academy in London has asked its followers to draw their artworks. Introducing "The Young Artists" Summer 
Show, an open and free exhibition to give recognition to talented young artists age 5-19 years is taking place this year both online and on-site at the Academy. Such efforts are very constructive and creative. They may even attract the attention of children, young adults or even people who otherwise might never have looked at a piece of art. (Seifman,2020)

Upon their limited reopening to the public, various techniques and strategies were employed by arts and cultural venues to reduce the risk of transmission of COVID-19. These included: Reducing the allowed attendance numbers and restricting the number of simultaneous visitors a pre-booked timeslot; mandatory wearing of masks; the provision of hand sanitizer; one-way routes through exhibitions; Perspex screens between staff and guests; installation of no-touch bathroom fixtures; and temperature-checks upon arrival.

Moving from the gallery to the auction world, the dynamics of transitioning online and interacting at a distance have evolved differently. Auction houses are central to the secondary Art market. They focus on the profitable resale of works by established artists and artists whose work promises short-term commercial gains (Cappellazzo, 2020).

With the pandemic's sudden lockdown, auction dealers find travel restrictions especially disruptive. they now must interact remotely for private sales, online auctions, sourcing work, and doing valuation. Yet private sales are not sufficient to mitigate COVID-19's disruption. As in-person auctions were postponed, which led to forming a task force that of qualified people to joined strategized pivoting auction sales online. Nevertheless, online auctions currently have limits for top prices. They lack the drama of a live auction that stimulates astronomical bidding among elite clients. And this can be done by huge auction houses that have lots of trusted clients.

For collectors, trust is essential. While purchasing Art is an economic transaction, personal ties are crucial, particularly at the 
Repercussions of Coronavirus pandemic and its impact on the Aesthetic Variables of Contemporary Visual Art and Artists

higher end of collecting (Moulin,1987). For that some collectors limited their purchases through the covid-19 lockdowns to dealers with whom they have established old relations and is skeptical of digital Art purchases, Others think online platforms enhance the engagement with the Art world when this is not possible for collectors to examine the Art piece physically although some find the increased transparency in pricing on some online platforms a major benefit many online viewing rooms at Art fairs now list prices, rarely posted during in-person fairs or gallery exhibitions. and this benefits new collectors as well, who lack trusting relationships with dealers (Velthuis, 2005, p 65).

On the other hand, some collectors reduce their engagement with the Art market. This results from the limited way in which they use online platforms, their desire to evaluate unique works in person, their need for trusting relationships with dealers, and the lack of stimulating collective effervescence from online interactions. (Buchholz et al,2020)

The contemporary Art world offers lessons for how other markets may be impacted by the COVID-19 crisis beyond purely economic ramifications. Markets that heavily rely upon developing informal relationships based on trust and those that sell goods whose value rests on rarified and unique experiences rather than standardized metrics will likely face more tumult when moving their operations remotely. While some experiences can occur online or without physical co-presence, consumers often pay not only for the experiences themselves but also for the effect and status derived from immersive consumption.

\subsection{The effect on Artists}

Increasingly over the last ten years, artists have learned to depend on online tools to run their Art business and market their artwork. Now, more than ever, the need to harness and tap into the power of the internet have increased trying to make connections and readapt with the new circumstances that were forced by the pandemic. 
As the coronavirus outbreak continues to take over headlines, artists around the world are responding to the situation in their way, learning to adapt with its Implications as Art fairs, exhibitions and workshops are indefinitely put on hold. It has rapidly affected careers Leavening a clear imprint on their artwork and their aesthetic expression approaches.

In response to cancelled Art shows, exhibits, conferences, workshops, and coaching sessions, artists are taking a positive approach to overcome the challenges of the Coronavirus. Some visual artists are focusing more on online creativity coaching for money, offering some online options to support themselves and overcome the financial deficit that coronavirus raised.

Full-time artists are taking their workshops online some started their websites for functional use, with an online gallery, social media following, and newsletter subscribers, starting online support groups. In a more obvious way, Art promotes creativity and exercises the brain. While creativity is the core of adaptability that gives the ability to acclimate to the new realities the artist's face one of these adaptations is heading to online networks that allows the artists not only to communicate with those around the world but also creates ways to connect with his audience and other artists as well.

Artists are also using this forced downtime due to lockdown to create new work for the future, experiment with new methods, learning new skills, and delve into longer-term projects. As some set aside a dedicated space in their homes as a working ground in making their artwork, to maintain the creativity of the brain active and healthy.

Practices have remained relatively stable for some artists, other artists who deal with political themes and street artists, like Banksy, have explicitly responded to the pandemic in their work (Belcove,2020). Prominent artists with large studios and numerous assistants report that they made changes that are more drastic not just in their themes, but also in their production 
Repercussions of Coronavirus pandemic and its impact on the Aesthetic Variables of Contemporary Visual Art and Artists

process. They adapted by delivering materials to their assistants' homes or by pausing production (Cohen,2020).

Meanwhile, the process of exhibiting work publicly and building connections within the Art world inevitably involves interaction and the lockdown made it possible for them to attend more venues online through Zoom or other platforms, which was difficult before due to family circumstances and obligations.

Despite that, online exhibitions and social media platforms offer opportunities to the artists to circulate their work and engage with their peers; however, artists find these interactions aesthetically lacking in that, they do not get the same fulfilment from viewing artwork online. Socially, they also feel unfulfilled, as they do not experience the collective effervescence the powerful excitement of socializing with like-minded peers nor can they develop new connections remotely.

For some artists, it has taken a new level of social responsibility in educating the audience about the virus, engaging more with the online public by offering help and encouraging others to find an artistic voice and identification through the world of images, and try to develop their aesthetics in a continual process of refining vision which moves them towards new understandings about themselves and the world around them to overcome the isolation disturbances. Additionally, street Art about COVID-19 acts as public service announcements, solemn observations, and the occasional but crucial levity, as street artists are reflecting this new reality with their work.

Finding inspiration and motivation to create is more difficult during the coronavirus crisis because oftentimes, making Art is a social activity, many artists living in self-isolation or under strict lockdown measures turned inwards for inspiration and numerous hitherto unexplored paths, largely due to the inescapable state of introspection and the absence of physical human connection. 
Art is about inner exploration, creative expression, economic capital, social harmony, global connection, and respect for nature. Though the COVID-19 crisis has had a severe emotional and economic impact on the artistic community, artists are regrouping and reinventing themselves for this new normal.

Moreover, Art is a form of healing and recovery and provides solace and therapy during times of stress. It helps safeguard mental and spiritual health, and reduce barriers between people, cultures and languages. Art has also been used to spark social change and increase awareness about destructive facets of economic development, and sharing their messages with the audience, many artists talk about love and union, others seek to raise awareness; some have a more comical approach and others are simply curious observations of the new scenario in which they can find themselves. But some people are also inspired by the panic and chaos happening in their work. the elements that are most repeated in "Covid Art" are, as you can imagine, the masks, the toilet paper and the virus itself. the pandemic will end eventually, but Art never dies. The question is are we witnessing the emergence of a bacteriological movement?

\section{The practical framework}

In composing a brief study in the middle of the crisis, we admit the limitations of temporality, particularly given the constraints on field research. Intellectual modesty is desirable. As the crisis is still ongoing, we cannot know what large-scale transformations will occur in the longer term. We acknowledge that this time the research has been marred as most of our interviews were conducted before the surge in anti-racism protests, we do not address how this historic movement has impacted the Art world considering the content of work and the activities of Art market participants.

The researcher chose a set of applied models related to the subject of research, which served as technical and artistic indicators that led to the theoretical framework, based on the 
Repercussions of Coronavirus pandemic and its impact on the Aesthetic Variables of Contemporary Visual Art and Artists

descriptive analytical approach of a group of samples that revealed the results and conclusions, ultimately contributed to finding a new performance standard for the aesthetic process during the Covid-19 pandemic.

This chapter deals with the procedures followed by the researcher to achieve the current research goals in terms of the description of the research community, its sample and the preparation of the tool used in the analysis of samples.

\subsection{Research methodology:}

the researcher adopted the descriptive and analytical approach, being the most appropriate, and the closest to achieve the objectives of the research that covers a certain important aspect of the impact on either the artist approach or the philosophy that he a doubted in his artwork.

\subsection{Research community:}

given the large amount of work related to the Coronavirus pandemic that the artists accomplished it is not possible to statistically enumerate and identify, the researcher carried out an inventory and survey of the available work related to the research community, to select the sample and define it to cover the current research aims.

\subsection{Research sample:}

samples were chosen randomly from all over the world with different approaches, methods and philosophies because it is an ongoing effect the researcher tried her best in show different point of views, as some show support while others express their suffering, some chose to focus on the bright side of the chaos, each of them has reacted differently to the pandemic and has shown diffrent approach.

\subsection{Search tools:}


The researcher relied on the objective analysis in proportion to the topic of the research, highlighting the impact of the subject of the study to cover most of the prominent phenomena, focusing on intellectual, aesthetic and artistic indicators within the context of the theoretical framework.

\section{Sample (1)}

- Artist: Ernesto Muñiz

- Title: The Virgin Crown

- Art Type: Street Art

- Location: appeared on a wall in Madrid

- Date: March $13^{\text {th }} 2020$, the day before Spain went into lockdown.

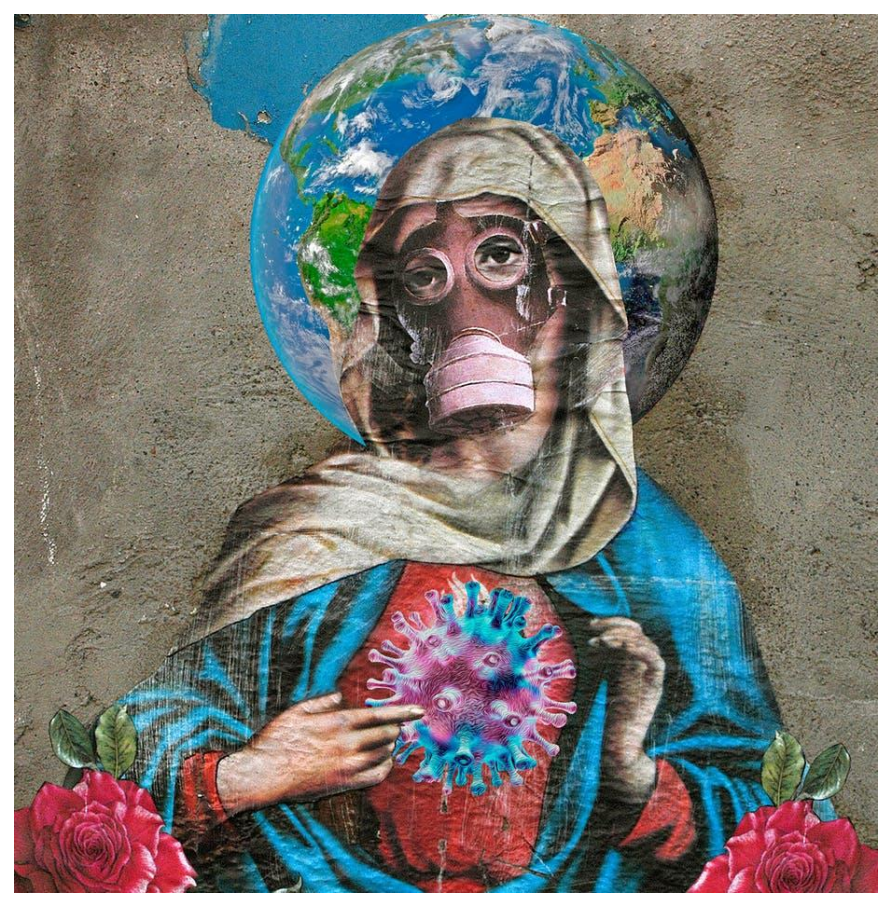

Figure 1: Erneto Munis, The Virgin Crown, Street Art, MadridSpain,2020. 
Repercussions of Coronavirus pandemic and its impact on the Aesthetic Variables of Contemporary Visual Art and Artists

While millions of people across Europe and beyond have been forced into lockdown during the COVID-19 pandemic, some artists used their time in isolation to create work using religious imagery to tell the story of the crisis. On the streets of Madrid, graffiti artist Ernesto Muñiz reimagined the imagery related to the Immaculate Heart of Mary as a means of interpreting the current situation.

The Virgin's heart becomes a rendering of the virus, the cause of the world's suffering. The Virgin herself is wearing a gas mask, yet her sorrowful eyes, pose and garments are all instantly recognizable. This image of the Virgin seems to suggest that we should place our trust in science, wear our masks and the suffering will pass.

She is no longer the icon calling for prayer, but she is a symbol of faith especially in times of crisis. This recourse to the image of the Virgin, in particular, should come as no surprise. To Catholics, she is the perfect incarnation of suffering, hope and love. Western cultures have long turned to the image of the Virgin Mother for comfort or to express ideas about unconditional love.

It seems that the coronavirus has prompted many people to turn again to a patchwork of religious and artistic practices weaving them together to give shape to their fear, but also to their need to embrace a creative community-building exercise.

No matter how secular and rational modernity or postmodernity might sometimes seem, it appears that some people still need to turn towards a spirituality and even traditional religious imagery to help them self. They need it to try to make sense of the world around Them, especially when Their lives seem more precarious and at the mercy of an invisible and unstoppable virus.

Sample (2)

- Artist: Banksy

- Title: Game Changer 
- Art type: Charcoal on Canvas

- Location: University Hospital South Hampton, UK

- Date: 2020.

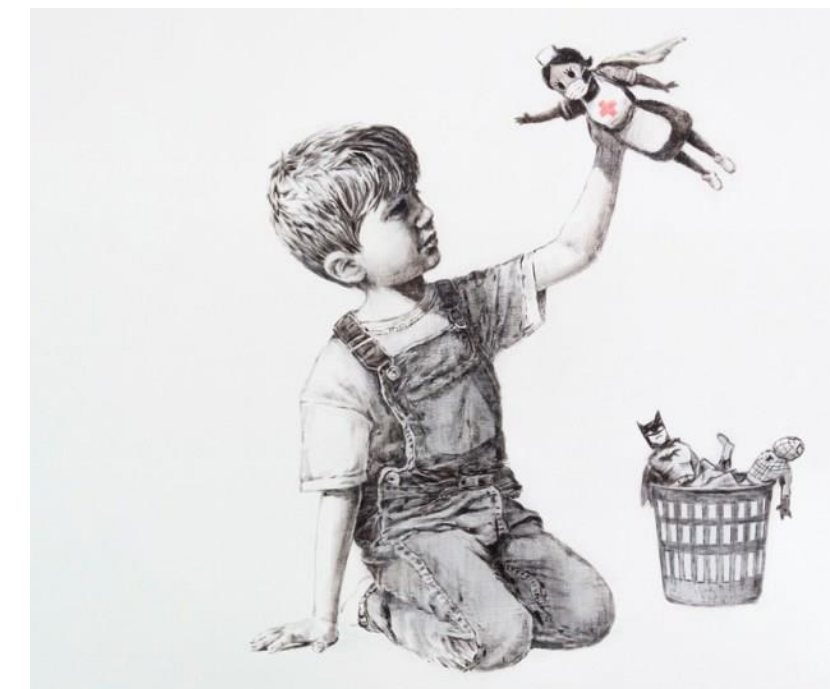

Figure 2 Banksy, Game Changer( Painting for the Saints(.

Charcoal on canvas. 2020

Enigmatic street artist Banksy has delivered another masterpiece with a very powerful message that's particularly amplified by the place it appears in - a British hospital. The incredible gift to the University Hospital South Hampton (UHS) came with the note, "Thanks for all you're doing. I hope this brightens the place up a bit, even if (it's) only black and white" and it's currently on display in its corridor.

The artwork epitomizes the idea of a picture being worth a thousand words, which is a trademark of Banksy's style in general, along with the black-and-white palette against which stands out a single red element, which in this case is the red cross on the medical worker's apron. The message is clear - medical workers are the superheroes amidst the coronavirus pandemic. Banksy named it "Game-Changer," however, with his permission, UHS has changed the name to "Painting for the Saints," paying tribute to the local football team which goes by the nickname of 
Repercussions of Coronavirus pandemic and its impact on the Aesthetic Variables of Contemporary Visual Art and Artists

"The Saints. "To erase any doubt that the artwork is, indeed,
Banksy's, the creator posted it on Instagram.
Southampton hospital family has been directly impacted by
the tragic loss of much loved and respected members of staff and
friends. The fact that Banksy has chosen us to recognize the
outstanding contribution everyone in and with the NHS is
making, in unprecedented times, is $\alpha v$ honor.

\section{Sample (3)}

\section{- Artist: Nikki Marie Smith}

- Title: Vincent Unmasked, Masked Girl with a Peal earing

- Art Type: Digital artwork

- Location: Online www.fineartamerica.com

- Date: May 2020

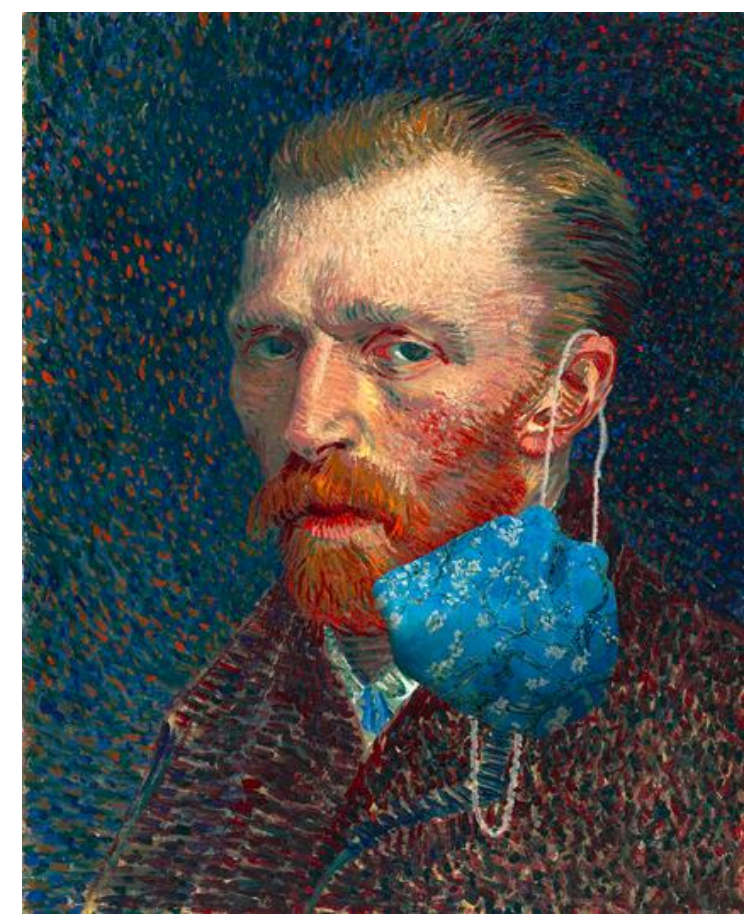

Figure 3 Nikki Marie Smith, Vincent Unmasked, digital artwork, May 11th, 2020 


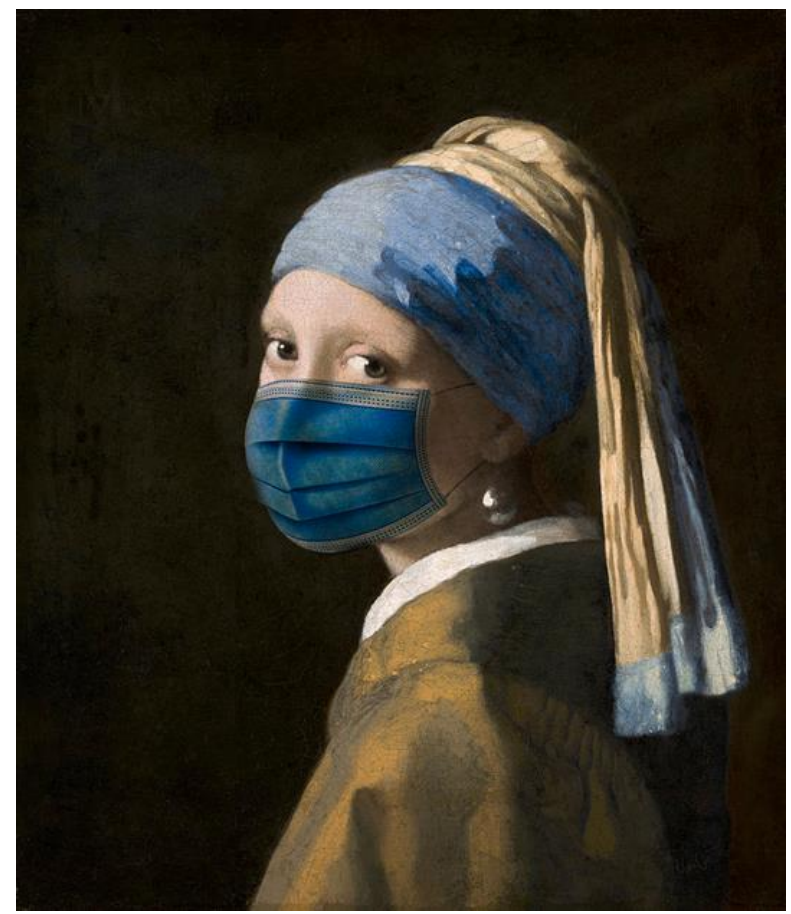

Figure 4 Nikki Marie Smith Masked Girl with a Pearl Earring, digital artwork. May 3rd, 2020

Nikki Marie Smith had a different approach mechanism, combining digital Art techniques with Pop Art philosophy emphasizing the elements of any culture, most often through the use of irony, in this case, is the elements are the original masterpieces of a famous artist.

The first is for the Dutch post-impressionist painter who posthumously became one of the most famous and influential figures in the history of Western art. Vincent van Gogh, the reimagined of the artist self-portrait in the time of our modern coronavirus pandemic, Vincent wears a mask to prevent the spread of Covid-19. For humor's sake, the mask will not stay on his missing ear. To extract a smile during the horrific and successive events of the epidemic outbreak that claimed many lives and caused a lot of tragic disturbance and sadness, the 
Repercussions of Coronavirus pandemic and its impact on the Aesthetic Variables of Contemporary Visual Art and Artists

artists' approach says Yes, it's OK to laugh; humor can be healing.

"Masked Girl with a Pearl Earring" is another inspiration to revive the Dutch Golden Age painter Johannes Vermeer oil painting by the same name "Girl with a Pearl Earring" from 1665, the artist wanted to give a tribute to old masters, during lockdown as an appeal to the public to commit to wearing masks for the sake of preventing the spread of COVID-19!

This artwork is part of her attempt to normalize maskwearing and encourage the people to share the message socially as a contribution to keep the community members safe! Sample (4)

- Artist: FAKE

- Title: Super Nurse

- Art type: Street Art

- Location: Amsterdam

- Date: May 2020

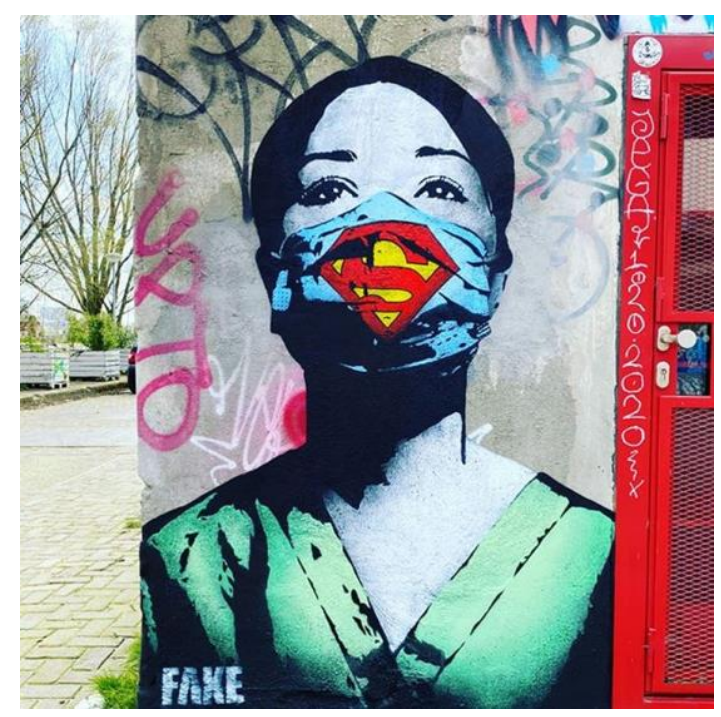

Figure 5. Fake. Super Nurse. painted as an 'ode' to all healthcare professionals around the world. 
As much of the world continues to shelter, those states and countries slowly easing restrictions are heading out into a world adorned with new art. Graffiti artists, street artists and muralists have been taking over public spaces during the pandemic, using their Art forms to express beauty, support and dissent.

One notable exception is street artists and graffiti artists, who have been busy incorporating COVID-19 into their work. The most prominent of these pieces is Banksy's "Game Changer". Many echo the same message as Banksy, that it's the nurses and front-line healthcare workers that are the real heroes in this crisis. This can be seen in the new work of Amsterdam-based street artist FAKE, whose mural "Super Nurse!" in the lead image shows a nurse wearing a face mask emblazoned with the Superman logo.

The Amsterdam-based street artist known as FAKE has created a mural, and free downloadable print of his new piece entitled "Super Nurse". FAKE's intention for this project is to raise awareness and as a thank you to all the healthcare and medical professionals risking their health currently battling COVID-19 worldwide.

\section{Sample (5)}

- Artist: Alaine DiBenedetto

- Title: 3 artwork (Stay home- Do it! -DJT Triumph)

- Art type: Street Art

- Location: Baton Rouge, USA

- Date: 2020 
Repercussions of Coronavirus pandemic and its impact on the Aesthetic Variables of Contemporary Visual Art and Artists

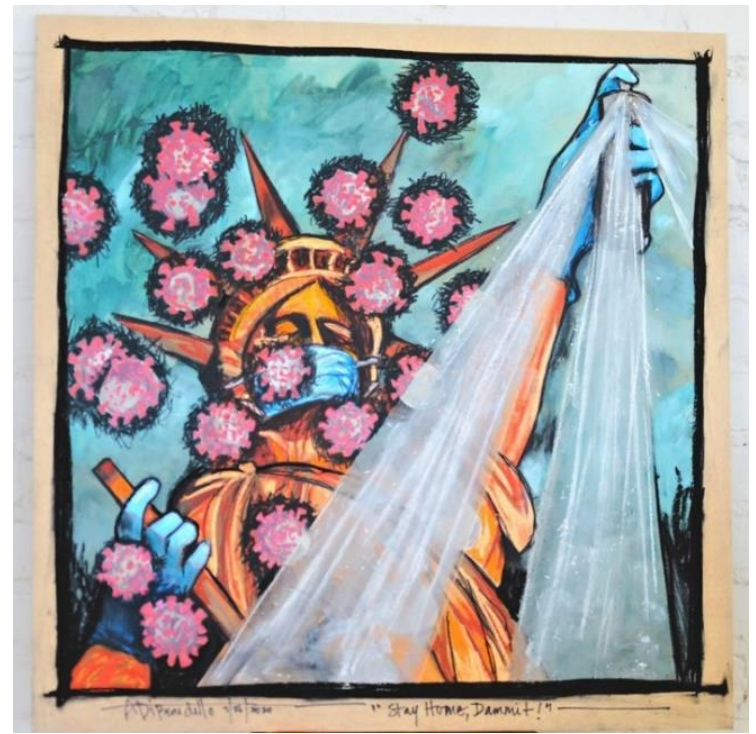

Figure 6 Alaine DiBenedetto. Stay Home, Dammit," a poster painting, Baton Rouge, USA, 2020

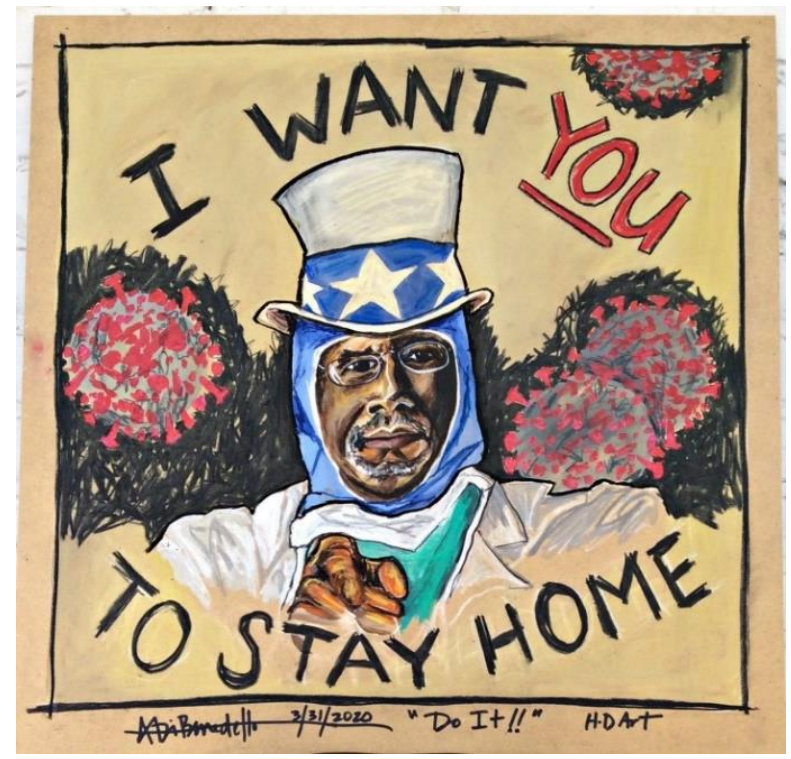

Figure 7 .Alaine DiBenedetto. Do It! A poster painting, Baton Rouge, USA.2020 
While many residents have been stuck at home due to pandemic lockdowns, an American Baton Rouge artist decided to use all that extra time for creative expression and to promote the critical message of health and government officials. Alaine DiBenedetto believes that artists have the important task of recording historical events, from cave drawings to the present day, especially during these kinds of events and crises, it is the artist job to be the visual and emotional recorders to combining great moments in history with the current situation.

On her fourth day of self-quarantine, DiBenedetto completed her first painting March 17 entitled Stay Home, Dammit, which depicts the Statue of Liberty wearing a mask and spraying a sanitizing substance. Her second painting Do It!, completed March 26, is a play on the classic U.S. Army recruiting poster featuring a retired neurosurgeon secretary Dr. Ben Carson a covid-19 survivor, instead of Uncle Sam, saying "I want you to stay home."

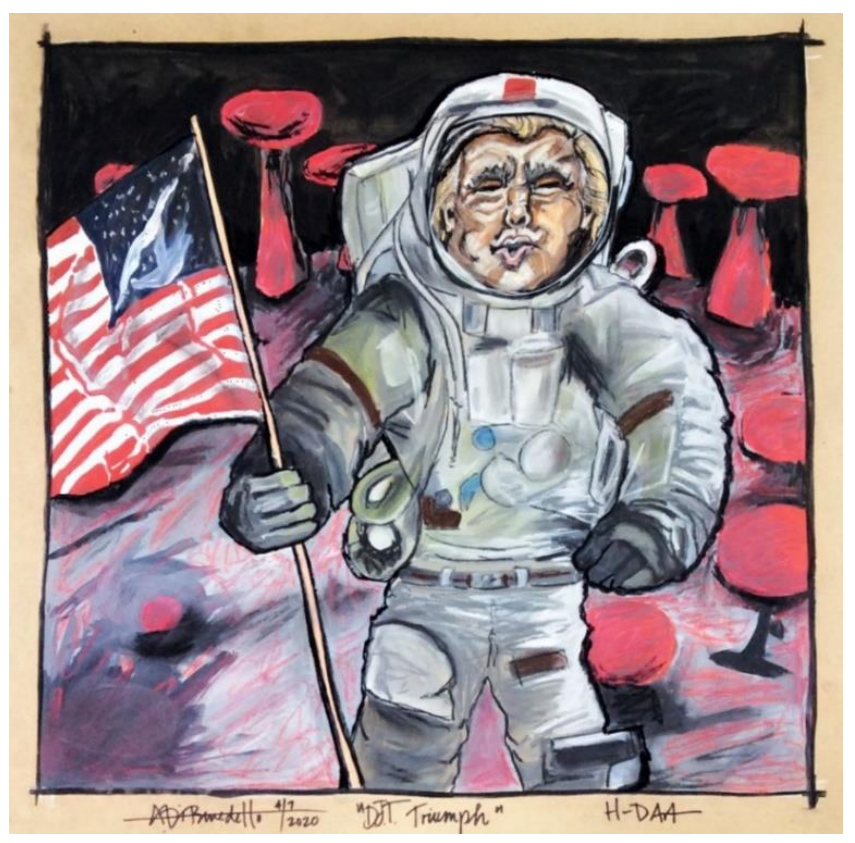

Figure 8, Alaine DiBenedetto, DJT Triumph, Poster Painting, Baton Rouge, USA.2020 
Repercussions of Coronavirus pandemic and its impact on the Aesthetic Variables of Contemporary Visual Art and Artists

The artist completed her third painting entitled $\boldsymbol{D J T}$ Triumph March 31. The painting depicts President Donald Trump in a space suit planting the American flag on a spore of COVID-19, reminiscent of astronaut Neil Armstrong planting the flag on the surface of the moon. In her opinion the president is making giant leaps to conquer the enemy and pulling the fragmented country together to fight the COVID-19 war, she also painted the hidden dove in the American flag to symbolize peace and unity.

\section{Sample (6)}

- Artist: Tom Young

- Title: Veil- Starry Night -Ghost Town

- Art type: Oil on canvas

- Location: Beirut, Lebanon.

- Date: 2020

Tom Young is an artist who spent more than a decade living and working in Beirut, the respected British artist has developed a deep emotional connection to the country. Through which his journey was incredibly moving and inspiring works of Art especially during the Coronavirus pandemic.

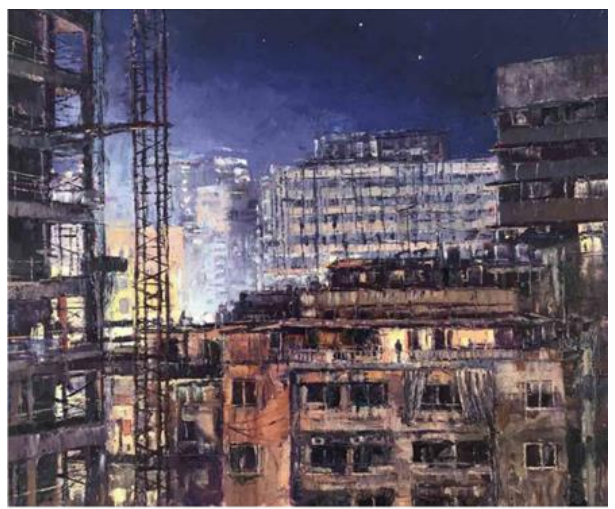

Figure 9.Tom Young. Starry Night Painted during the lockdown, oil on canvas $54 \mathrm{~cm} \times 65 \mathrm{~cm}$. March2020 


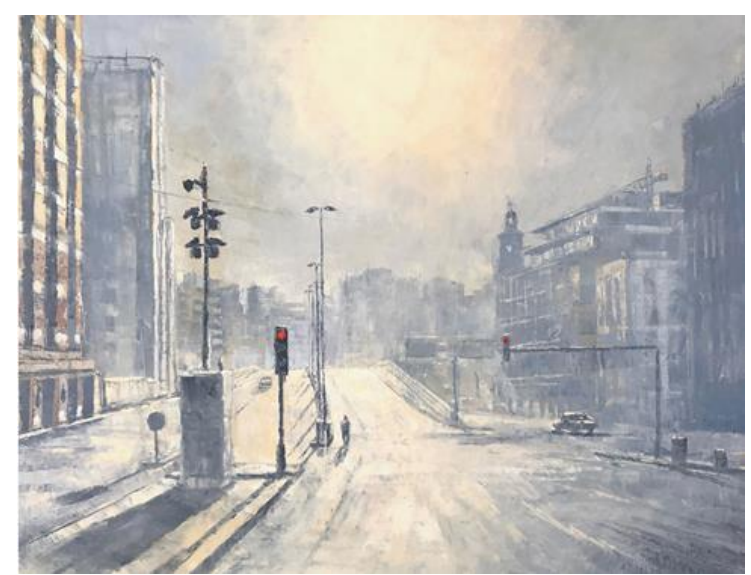

Figure 10. Tom Young. Ghost Town Painted during the lockdown, oil on canvas, $60 \mathrm{~cm} \times 80 \mathrm{~cm}$, April 2020

The artist concentrated on ordinary people during the coronavirus Biuret lockdown in 2020, he noticed the same distant figures looking out from their balconies each night, glimpses of urban melancholy, hoping for better news. Occasionally the city rang with the sound of banging pots and pans to honor heroic doctors and medical workers on the front line. Another work focused on picturing the city during the lockdowns in a dramatic way, the streets are empty, the occasional taxi or delivery moped, whizzes past, red lights have lost their meaning, CCTV cameras look down on eerily quiet road junctions, pronouncing a new age of surveillance, this period of isolation and the increased dependency on the internet for social communication will only exacerbate our precarious status as a globalized society which is being watched at all times.

Young showed some interest in facemasks from another perspective as a modern-day veil. A version of the cultural garment which women must wear in public in the most conservative Islamic societies for centuries is suddenly compulsory for everyone in the world. Many will have some idea of what those women have been experiencing: censorship, frustration, the feeling of entrapment, the inability to convey or 
Repercussions of Coronavirus pandemic and its impact on the Aesthetic Variables of Contemporary Visual Art and Artists

read facial expressions in public, unable to communicate, cut off from each other. This has wider implications as a symbol of being gagged where voices are suppressed, stories of abuse and suffering are 'Haram', or as they say in Lebanon 'Aib' (shame). Some subjects must never be mentioned. Whether we agree or disagree with the artist perspective, we have to admit part of it is true, it was a change that was forced on all men and women, it led us to think about what Muslim women abandoned to obey God.

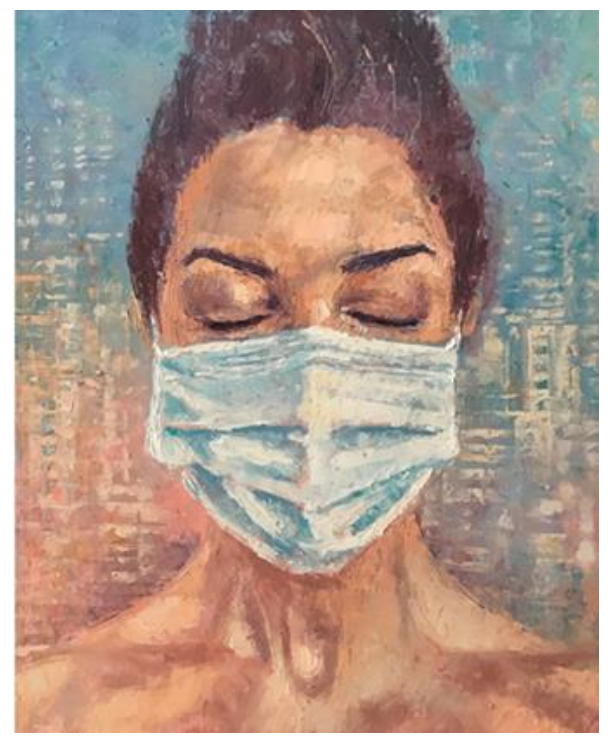

Figure 11, Tom Young, Veil (Silence) oil on canvas

$$
65 \mathrm{~cm} \times 54 \mathrm{~cm}, 2020
$$

\section{Sample (7)}

- Artist: YGARTUA

- Title: Under Siege/ The Battle

- Art type: Oil on canvas

- Date: 2020

Ygartua's whimsical approach highlights the volatility, the unpredictable manner how this virus conducts itself changeable, volatile, erratic and elusive. He portrays the virus in all our cities of the world from the Trevi Fountain in Rome to Notre Dame 
with the Gargoyles in Paris, Gaudi in Barcelona, St. Basil's Cathedral in Moscow, Time Square, New York, Piccadilly Circus, London. The artist believes that in a globally connected world, we are obligated to each other to find a solution, to share our discoveries and work together to conquer this unbelievable, unimaginable beast.

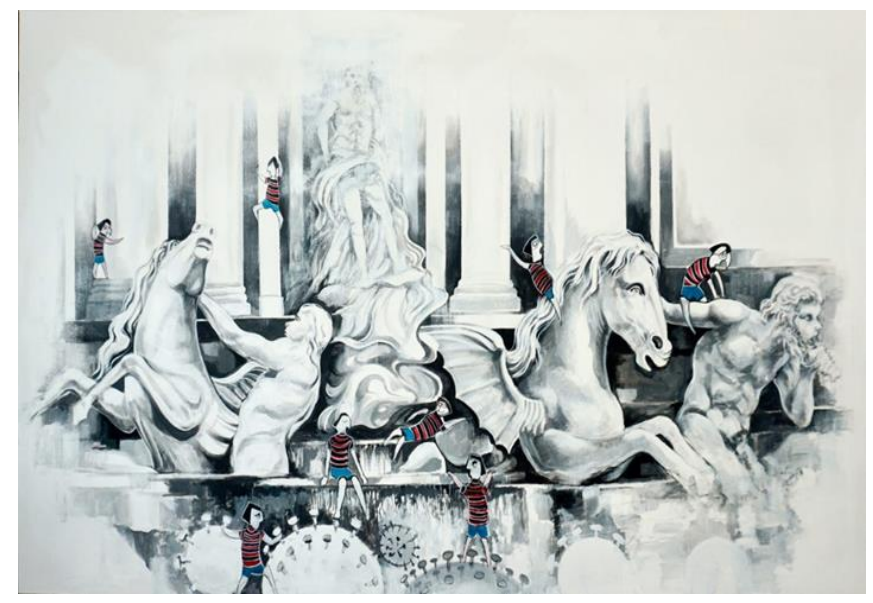

Figure 12 YGARTUA, UNDER SIEGE Trevi Fountain, Rome.

$72 \times 48^{\prime \prime}, 2020$

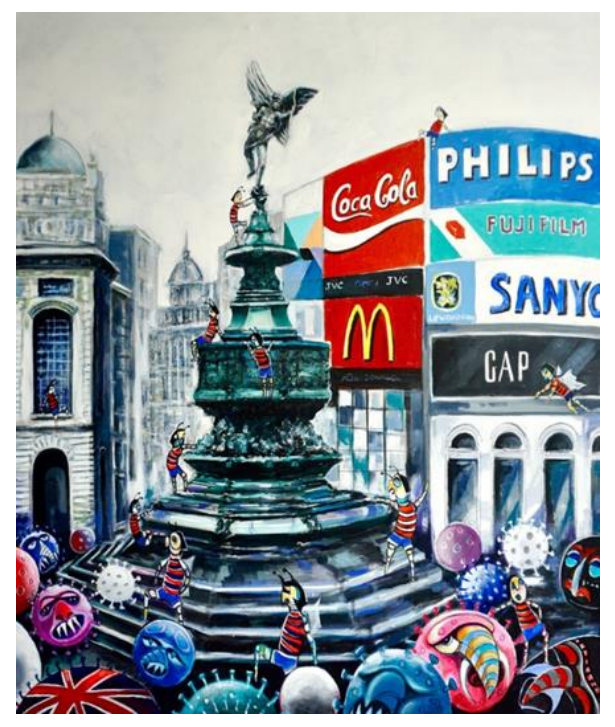

Figure 13 YGARTUA, UNDER SIEGE London, Piccadilly Circus $48 \times 60^{\prime \prime} .2020$ 
Repercussions of Coronavirus pandemic and its impact on the Aesthetic Variables of Contemporary Visual Art and Artists

Ygartua takes us on a journey to the imaginary global kingdom of COVID-19. He envisages the Coronavirus with teammates (similar to that of the pilot fish that help the shark) spreading this dreaded virus from one city to the next. His perspective was to depict Covid-19 as a predator that came from the depths of the cosmos and took over the order of humans and we are no more than its prisoners. The predator is our lord and master and has rendered us helpless. It is out there like soldiers free to travel the world, but they will soon meet their fate, intervention will be upon them.

The artist interpreting and painting his thoughts about the Coronavirus is a constant battle between good and evil. he tries to imagine the more positive approach to battling it; through our healthcare heroes, which made him think about what other creatures create fear in every living being. he was curious to visually study the up-close photos of this dreaded disease, it encouraged him to do some research on the visual presentation of these cells, it enticed him to look further, been drawn in on the mystery, the artist started to enter into a dream-like state, applying his imagination to transform us onto the battlefield, it was like he was facing the war, the challenge to win-over and conquer this cruel beast. This is where his idea of paintings was invented.

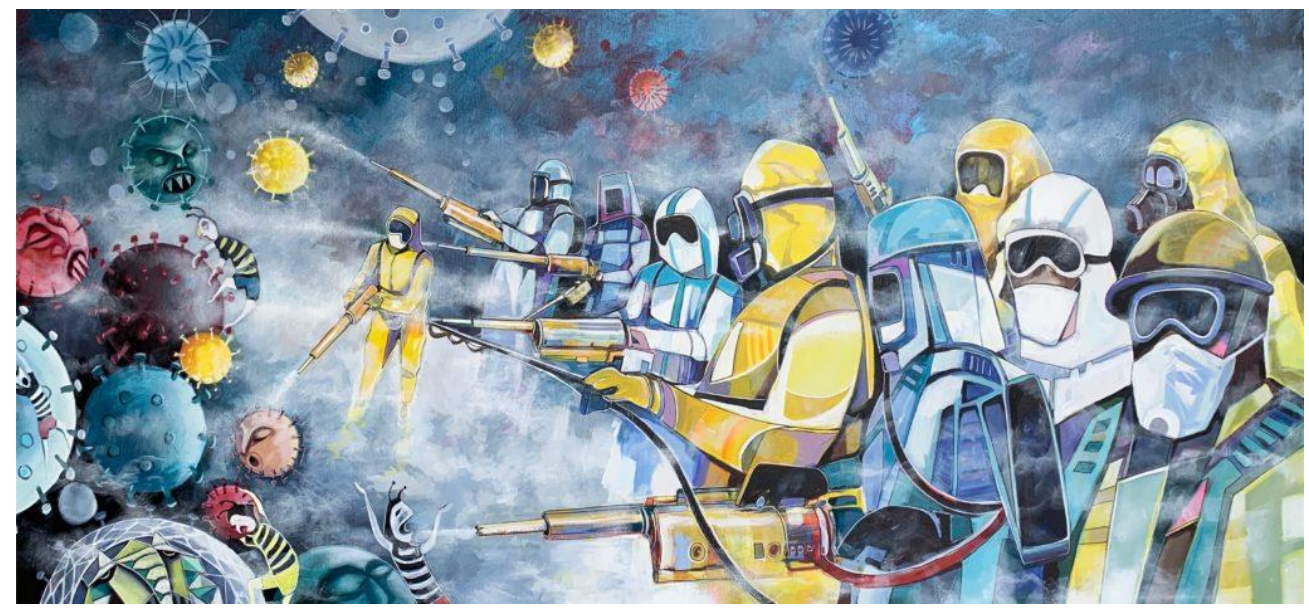

Figure 14 Ygartua, THE BATTLE..2020 
The battle is an out of this world experience as if they came from another planet, reminiscent of Star Wars, it has a similar effect, drawing on ideas from movies and reality today. For him, it is hard to imagine we are in the moment of a disease that needs this type of apparatus, his celestialism that began in 1972, when he painted creatures from other planets, also looked like they had protective gear on them, which helped him develop this modern style relating to the COVID-19 outbreak.

\section{Sample (8)}

\section{- Artist: Heather Olsen}

- Title: Health care Heroes Series

- Art type: Oil on canvas

- Date: 2020

Artist Heather Olsen is exceptional in her style of response to coronavirus pandemic happenings. The series of her work was inspired by the nurses and doctors who were the frontline fighters when the onslaught of Covid-19 hit. They selflessly worked nonstop literally passing out due to lack of food and sleep to try and save as many people as they can. They sacrificed themselves to treat others. Many healthcare workers were sleeping in their cars to protect their families from getting the virus. The artist was close to one of those heroes and watched carefully what they are going through, these are true heroes risking their own lives and sacrificing everything, they must save everyone else. The artist wanted to pay tribute to them as they are on the front lines of this battle. Getting Ready To Go Into Battle is a painting documenting the true events heroes getting ready for their fight against the virus wearing their fighting gear 
Repercussions of Coronavirus pandemic and its impact on the Aesthetic Variables of Contemporary Visual Art and Artists

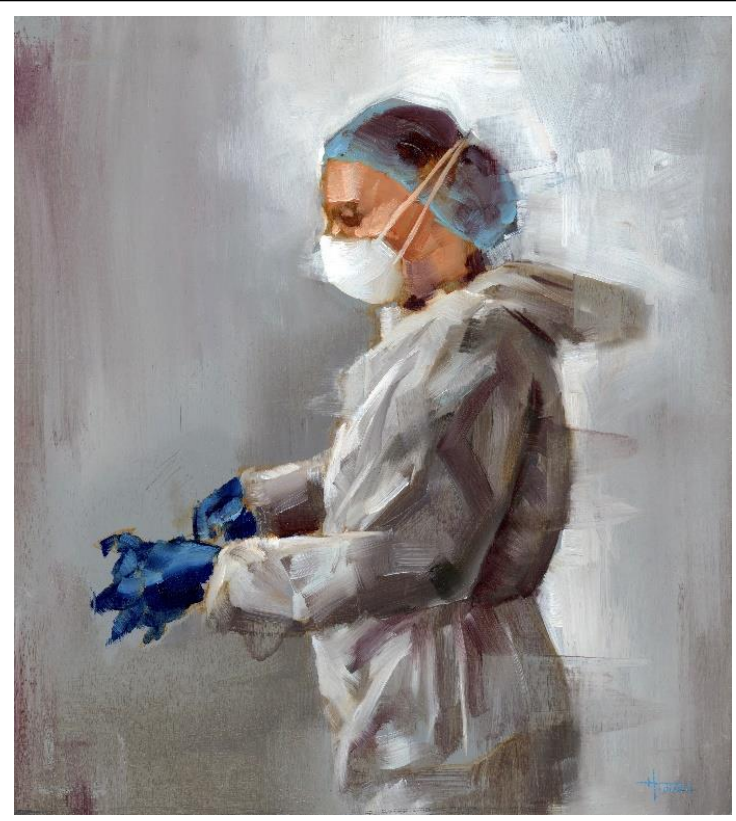

Figure 15 Heather Olsen, getting ready to go into Battle, oil On canvas. 2020

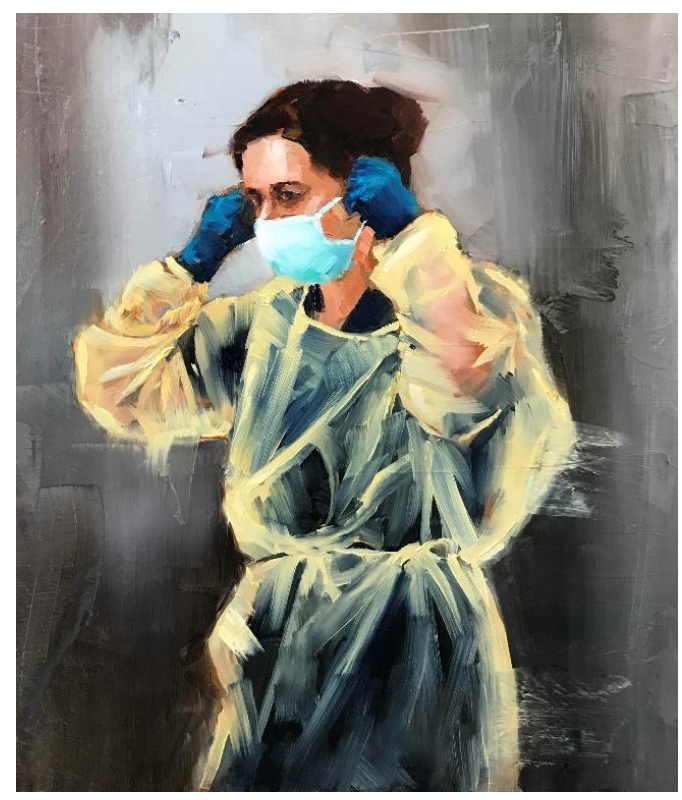

Figure 16, Heather Olsen, Gearing Up, Oil on Canvas, 2020 
Gearing up is another example, it was commissioned by the IHC healthcare team who travelled to New York to aid the crisis there during the Covid-19 epidemic. Given complete artistic freedom, the artist decided to depict a nurse wearing the IHC yellow body covering and putting on the blue mask. The world has never faced anything like this before and neither have these nurses and doctors. Yet they left their families and homes to travel to the epicenter of the virus outbreak to help save as many people as possible. They helped to save the world and was honored to be able to paint this tribute for them.

The front lines doctors and nurses were a major concern to the artist in her work Here we go she spotted the dedication in fighting the virus battle especially in New York City the heart of the pandemic, many of them said they felt scared and worried that they did not have the right skills and knowledge to be able to handle an epidemic like this. But they did it anyway. They went into the belly of the beast and did their job the best they could, not asking for glory or praise, but because of their desire to help people suffer. This painting depicts a nurse who is maybe unsure of herself, but ready to step in and save as many people as she can.

The last project Together we can do it is dedicated to Utah healthcare heroes, who have worked relentlessly through the coronavirus pandemic. The artist Heather Olsen piece is a special, one of a kind depiction of the fatigue, anxiety, and isolation felt by caregivers this past year. Presented in medical teams, Olsen was moved by each of their sacrifices, especially the nurses and doctors who went to help in New York last spring.

he use of texture, color, and gesture within each painting accurately depicts an almost tangible feeling and allows the viewer to empathize and relate to her work. Her love of Art and passion for painting and drawing is evident through her expressive artwork. 
Repercussions of Coronavirus pandemic and its impact on the Aesthetic Variables of Contemporary Visual Art and Artists

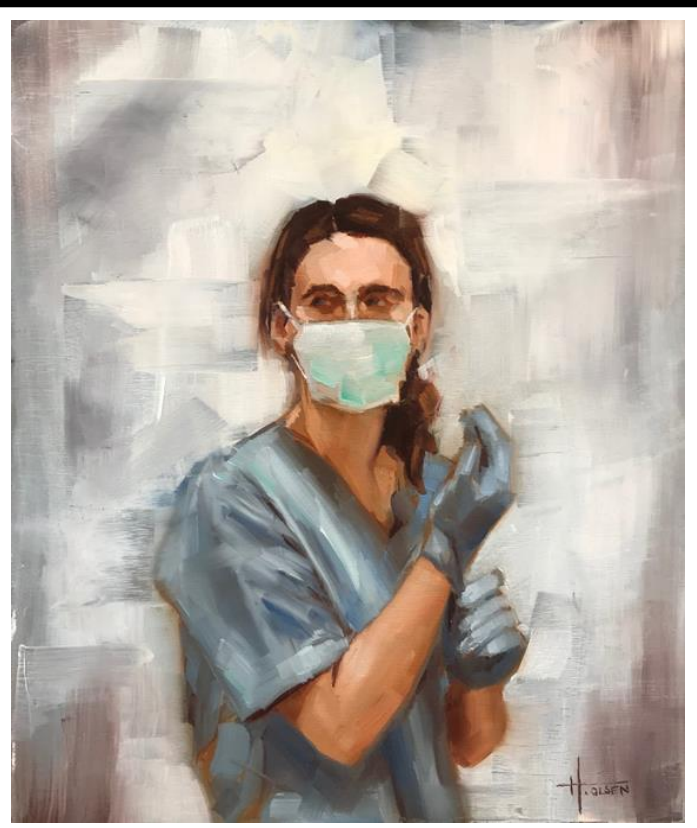

Figure 17 Heather Olsen, here we go, oil on canvas. 2020

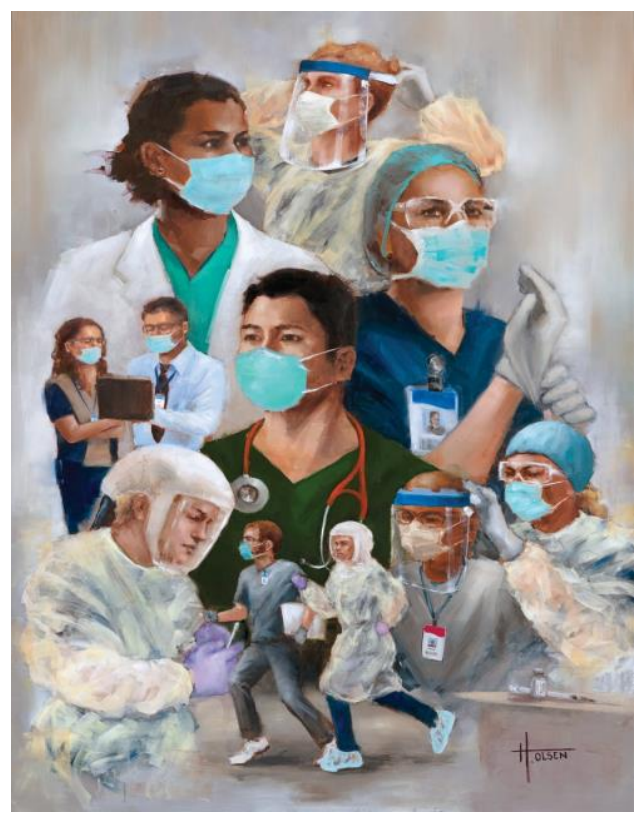

Figure 18 Heather Olsen, Together We Can Do This, oil on canvas. 2020 


\section{Sample (9)}

- Artist: Shu Yong

- Title: Health care Heroes Series

- Art type: Oil on canvas

- Date: 2020

A series of paintings created by renowned artist Shu Yong during the COVID-19 pandemic is currently on exhibition at the Hunan Provincial Museum in Central China's Changsha. the new exhibition Tribute to Heroes seeks to remember the medical staff and ordinary people who had contributed to the fight against the novel coronavirus. the Chinese artist has been creating one inkpainting every day since the novel coronavirus outbreak began in central China's Hubei Province in late January.

Shu Yong, a 46-year-old contemporary artist from central Hunan Province, has so far created some 120 works, mainly in the traditional Chinese ink painting style. Among his paintings are popular Chinese cultural icons like the Yellow Crane Tower in the form of landscape paintings, "not only because landscape paintings are a special Art form that people are used to, but also because they illustrate the communication between human beings and nature." The artist also created a new mini-series titled Breathing Together, which features portrayals of various cultural icons such as Vincent van Gogh and US artist Jackson Pollock inside a pair of human lungs. Each of these paintings is a tribute to the medic personnel who are fighting on the frontlines against the virus, saving thousands. 
Repercussions of Coronavirus pandemic and its impact on the Aesthetic Variables of Contemporary Visual Art and Artists

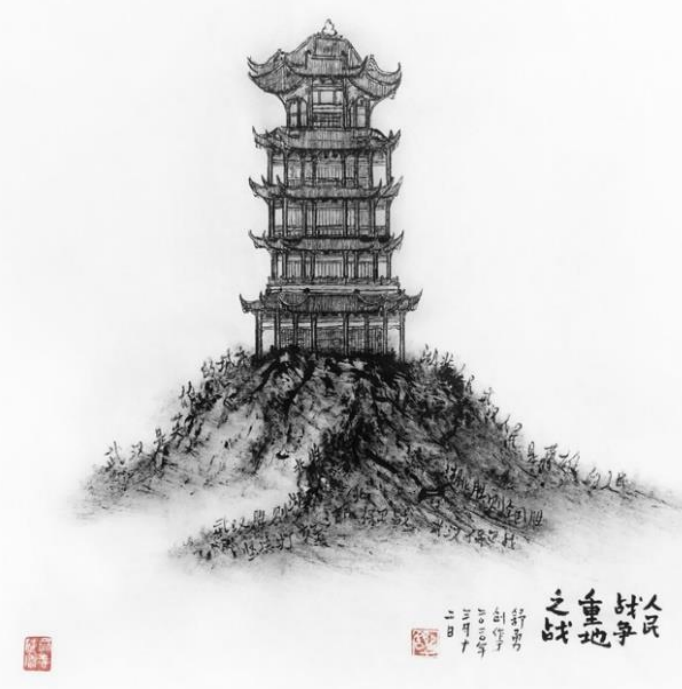

Figure 19, Shu Yong, Yellow cane tower, ink on paper, 2020

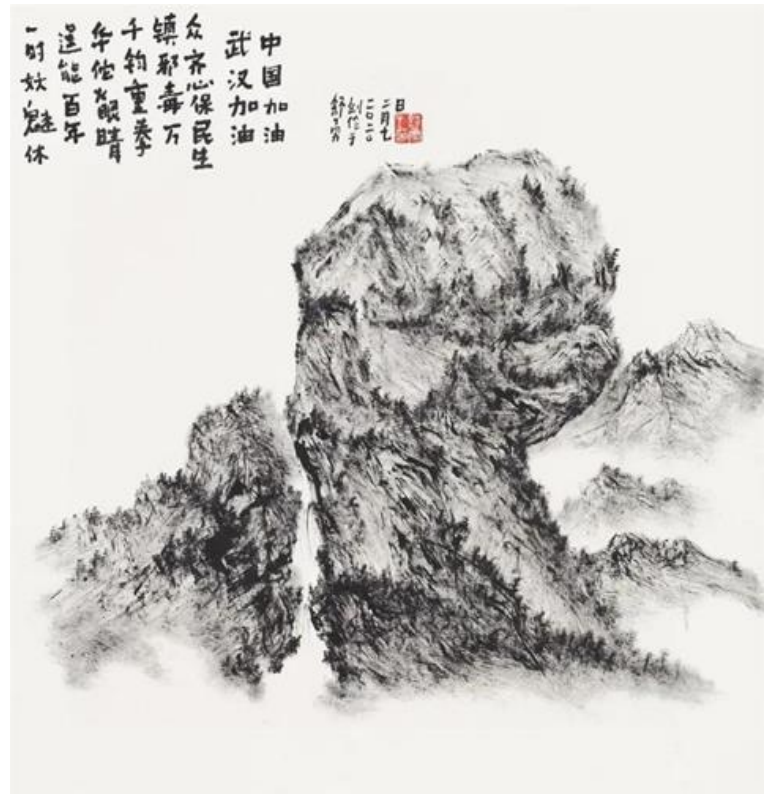

Figure 20, Shu Yong Fighting Wuhan, ink on paper,2020 

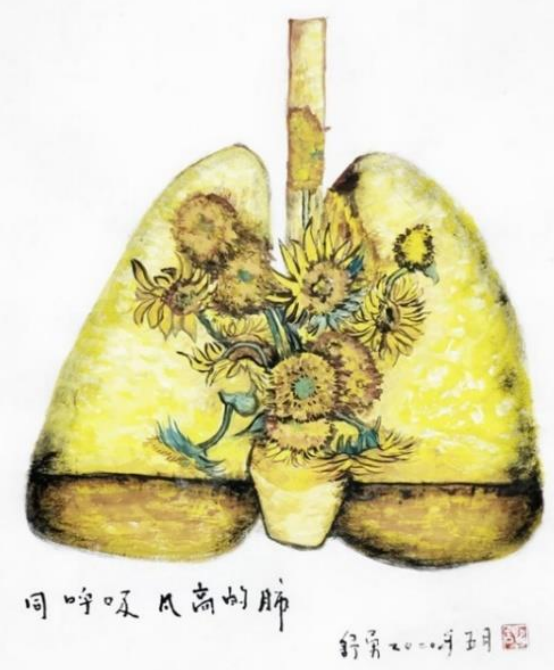

Figure 21, Shu Yong, Breathing together, Van Gogh, ink on paper, 2020

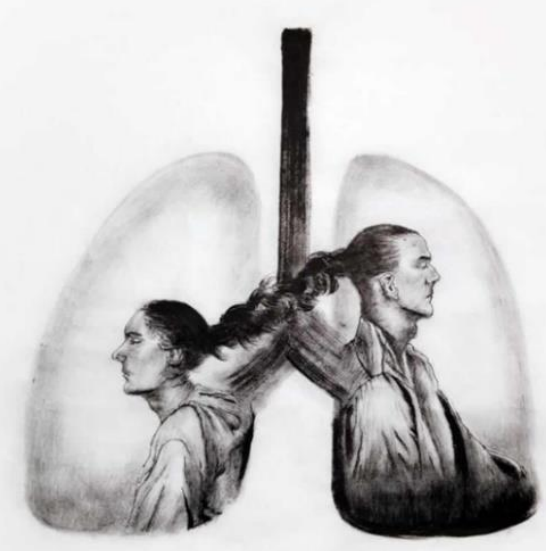

同呼吸阿英维部莫需的肺

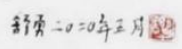

Figure 22, Shu Yong, Breathing together, ink on paper,2020 
Repercussions of Coronavirus pandemic and its impact on the Aesthetic Variables of Contemporary Visual Art and Artists

Shu wanted to combine stories about the global fight against COVID-19 with his positive thinking and artistic inspiration. In one of the paintings, "Fighting Wuhan" created by Shu on February 7, a towering mountain looks like a giant clenched fist pointing toward the sky. The fist symbolizes courage, determination, firmness and solidarity. These artworks on display are the result of Shu's determination to complete at least one painting every day after the COVID-19 outbreak began. the artist believes its mission for artists today to portray the common values of human beings and spreading the stories of china's brave battle with the virus. The artist has donated three of his paintings to the museum.

Sample (10)

- Artist: Rohan more

- Title: Vilayti Shauk Series

- Art type: Oil on canvas

- Date: 2020

As much of the world continues to suffer, Indian tribal artists, Art directors, painters, and illustrators are sending the message of hope and despair by reimagining a new and dystopian reality. Those states and countries slowly easing restrictions are heading out into a world adorned with new art. Artisans in India seek shelter in place by taking over social media spaces during the pandemic, by using their Art forms to express the duality of Mother Nature, support, and demure dissent. So, let us compose and dive into their current worldview through their canvas. 


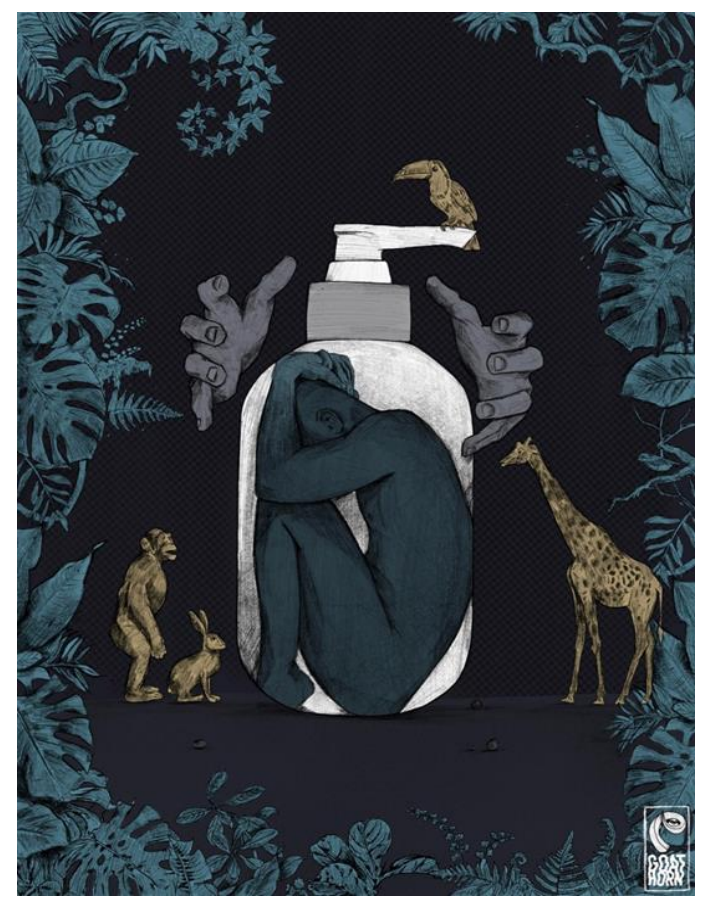

\section{Figure 23, Rohan more, the captive.2020}

Rohan more is a contemporary artist that has been making Art for the past five years and his breakthrough moment was with the series 'Vilayti Shauk', a tongue-in-cheek take on hype culture. This piece of artwork ironically symbolizes nature and the current state of lockdown in India. As humans, we often think we are beings of subjugation.

In January, there was an astonishing fact that came about, Australian feral camels declared to be a pest, and around 2012, Australia was culling down about 75,000 camels every year. Animals often bear the brunt of that. Now that we are confined to our homes, the earth finally has space to breathe and animals are hopefully getting a break from relentless human activity. That is what the artist wanted to express through his artwork, and for once "The Captor is now the Captive." 
Repercussions of Coronavirus pandemic and its impact on the Aesthetic Variables of Contemporary Visual Art and Artists

Sample (11)

- Artist: Mark louis Cohen

- Title: mask

- Art type: Oil on canvas

- Date: 2020

Mark Louis Cohen has aesthetically expressed his philosophy through his work. His philosophy of work revolves around the idea of wearing masks, most of us excel at wearing masks. We've done it all our lives. To fool our friends, our colleagues, even the ones we love. We wear these metaphorical "masks" to hide who we are and what we think because we want to fit in, gain approval and minimize conflict. Masking used to be a way to hide our emotions, like jealousy, anger or rage. But not anymore. Metaphorical masks are gone. Used up by thousands of dead people worldwide. We do not have time for metaphorical masks anymore.

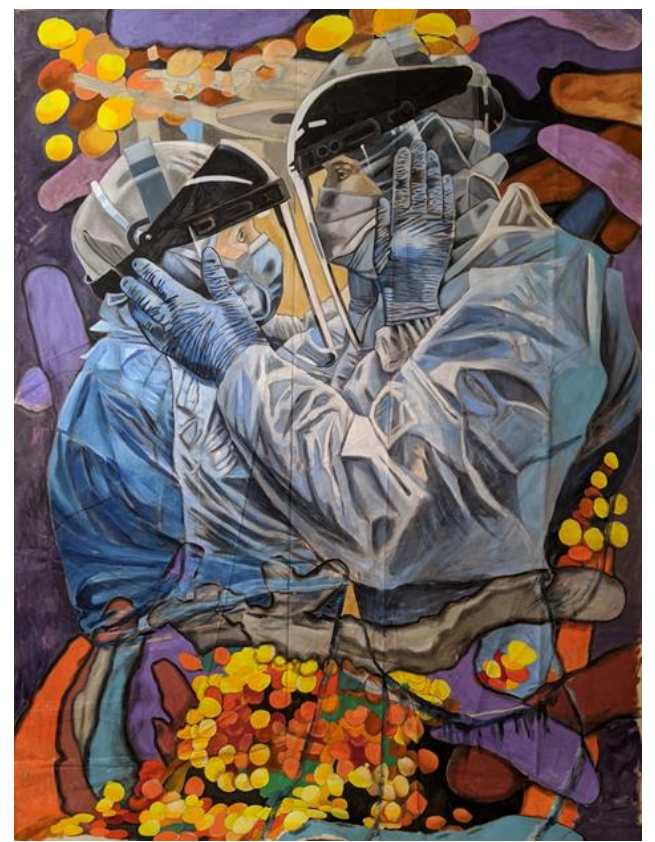

Figure 24 Mark Louis Cohen, COVID -19 \# 3, Oil on canvas 66" $w \times 84^{\prime \prime} h, 2020$ 


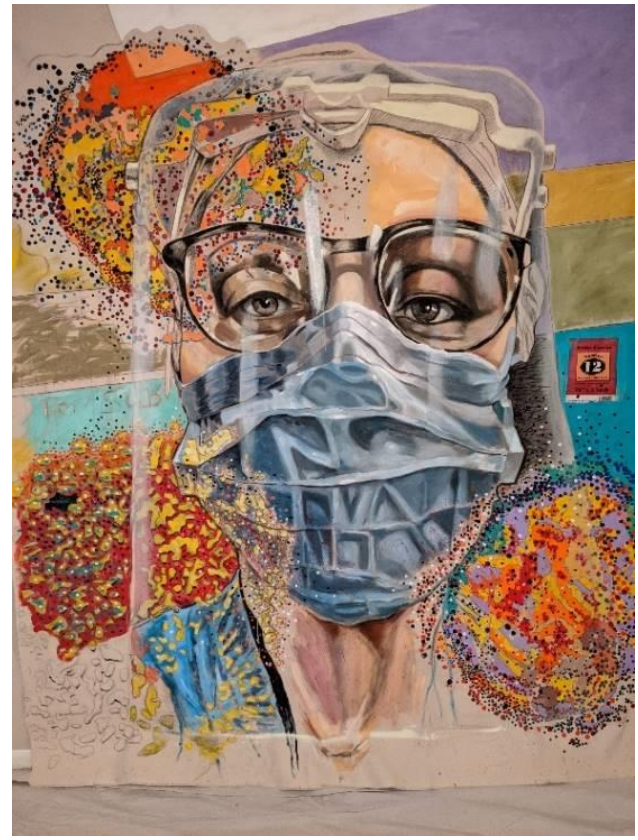

Figure 24 Mark louis Cohen, COVID-19 \# 6, Oil on canvas 84" w $\times 96^{\prime \prime}$ h2020

The time now is for surgical masks or clothed ones for those of us who cannot get a real mask. Hoping to be safe. From the virus. And every day, the doctors and nurses go to work wearing those same surgical masks that all of us want. Risking their lives and losing them. Because they took an oath to take care of us. Along with all the other people who have come to be recognized as indispensable. Who are all these heroes? We are all in their debt.

\section{Conclusion, study result and recommendations}

\subsection{Conclusion}

COVID-19 has taken a deep toll on the contemporary arts sector since the onset of the pandemic. The experiential and inperson nature of the arts whether visual arts, music, dance, or numerous other mediums has made it especially difficult to sustain as many venues have remained closed, or on limited operations which have put the Art industry in the face of new 
Repercussions of Coronavirus pandemic and its impact on the Aesthetic Variables of Contemporary Visual Art and Artists

challenges, arts organizations and artists have adapted and innovated to survive until conditions more conducive to physical and face-to-face engagement returns.

Many people tend to turn to the arts as a kind of catharsis and self-expression. During the period of social isolation, people tend to sing from their balconies and recreate Art using only items in their homes. The arts are a way to cope and process emotions that may be new or exacerbated by the global pandemic. Art can also be among the most powerful tools for health communication especially at times when trust in some government sources of information is in question, the arts can facilitate communication to diverse audiences quickly and widely, Artists are trusted community members and influencers. They can make critical information more personal and culturally relevant, understandable, and memorable. Artists are among those threatened by extreme financial uncertainty, the call cites. By using arts-empowered approaches to communication and coping, they also help employ artists and sustain arts organizations.

It is no surprise that artists are getting creative with new ways to build communities, support themselves and others, and maintain aesthetic values. While the way we are used to doing business in the Art world has temporarily changed, artists are finding new ways to innovate, move online, and stay connected. We may be mourning the loss of cancelled events, shows, and fairs, but there are new opportunities to connect and bring Art to new audiences during this time.

Artists and creatives are among the most severely affected workers by the COVID-19 crisis due to cancelled events, some experienced a decrease in creative work that generated income and yet do not have a post-pandemic recovery plan. meanwhile, isolation and lockdowns made it hard for artists to access the supplies, resources, spaces, or people necessary for their work, The four most critical needs for artists to sustain their work during the pandemic: Unemployment insurance, negotiable business loan, food/housing assistance, and affordable healthcare. 
And yet, some dedicate their artistic practice to raise community spirit and morale, create community cohesion, or lighten the COVID-19 experience of the community, as well as show their gratitude and pay tribute to healthcare members who are the true fighters in this battle.

\subsection{Study Result}

Through the observations of the researcher and her readings of the dimensions of the influence the subject of the study, came to the following results:

1. As the pandemic wears on, people around the world continue to live in self-isolation or under strict lockdown measures, this includes many members of the Art community.

2. Due to the COVID-19 pandemic and the effects it had on the world financial health, artists and freelancers must adapt as many major projects have been cancelled or put on hold with many theatres, galleries, shops, bars, and other venues closed, local artists. They face a daunting challenge to make their efforts noticeable.

3. The pandemic has taken a significant toll on arts venues and creators, although some artists recognize the positives that have come from the forced changes in their professional lives.

4. COVID-19 has accelerated the Art World's adoption of technology that can make Art more accessible and helped people to embrace it. Many institutions have provided alternatives by shifting to virtual exhibitions and platforms.

5. Digital platforms like Instagram, Facebook, are already woven into the fabric of the Art world, but in the absence of physical spaces, they have turned into lifelines for community and communication.

6. Most artists say that being able to work during the pandemic has provided both a coping mechanism and a means of expression. While working alone may suit some 
Repercussions of Coronavirus pandemic and its impact on the Aesthetic Variables of Contemporary Visual Art and Artists

creatives, others feed off intimate interaction and visual stimulus from beyond their immediate world.

7. In the absence of physical human connection and with movement drastically limited, many artists have had to turn inwards for inspiration. Whether that means reaching into the back catalogues of their memories or creating new and entirely imagined worlds and landscapes, the creative response to the coronavirus crisis has been extraordinary.

8. Artists have always been exceptional in their style of response to community happenings around them, for some artists, the pandemic has planted seeds of inspiration.

9. Some artists dedicated their work to raise awareness of the virus risks and the importance of keeping social distance or wearing face masks, others wanted to pay tribute to the healthcare members as they are on the front lines of this battle.

10. Street artists have taken on the empty streets to express themselves and spread awareness about the virus through graffiti and murals.

\subsection{Study Recommendation}

1. Conduct more research to explore the long-term impact of different aspects of the COVID-19 pandemic on the work of artists, their methodology and philosophy.

2. The researcher recommends conducting a detailed study aimed at detecting the COVID-19 pandemic influence on Art methodology and in the middle eastern countries.

3. The researcher recommends studying the transformations in the methodology and its effect on aesthetics and spiritual values in the Kuwaiti Art movement during COVID-19 isolation and lockdown.

4. The researcher proposes to study the aesthetics of new technologies used in contemporary Art in the twenty-first century. 
5. The researcher recommends conducting a detailed study aimed at detecting the role of technologies in promoting artwork and its contribution to changing the concept of conventional exhibitions and Art galleries.

6. There is a need to explore public awareness of attitudes towards positive contribution of Art during crisis and major pandemics in educating society and raising the sense of responsibility towards the community.

\section{References}

1. Bartley, Jonathan. (2020) Coronavirus: Environmental destruction 'paused' by lockdown measure. Sky News-BBC.UK.

https://news.sky.com/story/coronavirus-enviromental-destuctionpaused-by-lockdown-measures-11982992

2. Becker, H. (1982). Art Worlds. Berkeley: University of California Press.

3. Belcove, J. (2020). 16 Contemporary Artists Respond to the Covid19 Crisis with Poignant New Works, Robb Report, April 10th. https://robbreport.com/shelter/artcollectibles/gallery/contemporaryartists-covid-19-new-works2911980/mika/. Accessed 12 June 202

4. Buchholz, Larissa. Fine, Gary Alan\& Wohl, Hannah. (2020) Art markets in crisis: how personal bonds and market subcultures mediate the effects of COVID-19. American Journal of Cultural Sociology (Published: 07 October 2020) 8:462-476https://link.springer.com/article/10.1057\%2Fs41290-020-00119-6

5. Cappellazzo, A. (2020). Contemporary Art Market in Extraordinary Times. JP Morgan Webcast. June 11.

6. Cohen, A. (2020). How Artists with Large Studios Are Supporting Their Assistants and Making New Work, Artsy, April 27th. https://www.artsy.net/article/artsy-editorial-artists-large-studiossupporting-assistants-making-new-work. Accessed 12 June 2020.

7. Cohut, Maria. (2020) COVID-19 global impact: How the coronavirus is affecting the world.

https://www.medicalnewstoday.com/articles/covid-19-global-impacthow-the-coronavirus-is-affecting-the-world

8. Esaak, Shelley. (2013). "What is "Contemporary" Art?". https://www.thoughtco.com/what-is_contemporary-art-182974

9. Essak.Shelly. (2002). "Contemporary Art " https://en.wikipedia.org/wiki/Contemporary_art\#cite_note-Esaak-2 
Repercussions of Coronavirus pandemic and its impact on the Aesthetic Variables of Contemporary Visual Art and Artists

10. Gerlis, Melanie. (2020) Art market report shows the severe impact of Covid-19. Financial Times.UK.

https://www.ft.com/content/ff6530b4-1c40-497c-bd23c5a70e552401

11. Getty. J. Pual. (2000) about contemporary art?

http://www.getty.edu/education/teachers/classroom_resources/curricu la/contemporary_art/backg round1.htm

12. Gummer, Amanda. (2020) Coronavirus: Why spending so much time with our children could have unexpected benefits. Sky NewsBBC. UK. https://news.sky.com/story/coronavirus-how-lockdownlife-could-benefit-some-families-11981855

13. Hodgkinson, Tom. (2020) Coronavirus: How lockdown has given us more time for life's simple pleasures. Sky News-BBC.UK. https://news.sky.com/story/coronavirus-how-lockdown-has-given-usmore-time-for-lifes-simple-pleasures-11983585

14. Internet Encyclopedia of Philosophy. Retrieved 28-02-2021.

15. Lalande, Andre. (1960). Technical and critical vocabulary of the philosopher 8 Paris: Presses Universities de France

16. Moulin, R. (1987). The French Art Market: A Sociological View, trans. Arthur Gold hammer: Rutgers University Press

17. NYU Steinhardt, Contemporary art, Department of Art and Arts Professions, New York https://steinhardt.nyu.edu/programs/arteducation/art-education-definitions

18. Page, Jeremy; Hinshaw, Drew; McKay, Betsy (2021). In Hunt for Covid-19 Origin, Patient Zero Points to Second Wuhan Market. New York- https://www.wsj.com/

19. Schumaker, Erin. (2020). Timeline: How coronavirus got startedThe outbreak spanning the globe began in December, in Wuhan, China. https://abcnews.go.com/Health/timeline-coronavirusstarted/story?id=69435165

20. Seifman, Richard. (2020). Coronavirus and Art: How Quarantine Impacts Museums. https://impakter.com/coronavirus-and-art-howquarantine-impacts-museums/

21. Slater, Barry Hartley. (2003) Aesthetics | Internet Encyclopedia of Philosophy University of Western Australia.

https://iep.utm.edu/aestheti/

22. Thomas Munro, "Aesthetics", The World Book Encyclopedia, Vol. 1, ed. A. Richard Harmet, et al., (Chicago: Merchandise Mart Plaza, 1986), p. 80

23. Velthuis, O. 2005. Talking Prices: Symbolic Meanings of Prices on the Market for Contemporary Art. Princeton: Princeton University Press. 
24. Wikipedia. the free encyclopedia. (2020) Impact of the COVID-19 pandemic on the arts and cultural heritage.

https://en.wikipedia.org/wiki/Impact_of_the_COVID-

19_pandemic_on_the_arts_and_cultural_heritage

25. Zangwill, Nick. "Aesthetic Judgment", Stanford Encyclopedia of Philosophy, 02-28-2003/10-22-2007. Retrieved 07-24-2008. 